UDK 811.163.42’282(497.5 Reka) Izvorni znanstveni rad Rukopis primljen 12. II. 2018. Prihvaćen za tisak 6. V. 2018.

\author{
Mijo Lončarić \\ Zagreb \\ mijo.loncaric@gmail.com
}

\title{
OSVRT NA KAJKAVSKI I ŠTOKAVSKE GOVORE REKE KOD KOPRIVNICE
}

\begin{abstract}
U Reki se govori kajkavski i štokavski, i to tri idioma: kajkavski (s dvije starije i jednom novijom varijantom) te dva štokavska. Većina Hrvata govori, odnosno govorila je kajkavski, a manji dio govori istočnobosanskim, ijekavsko-šćakavskim dijalektom. Srbi govore novoštokavskom (i)jekavštinom (,novoštakavskom”), istočnohercegovačkim dijalektom. Kajkavski govor, koji je moj rodni idiom, istražio sam za Hrvatski jezični atlas (punkt 37a) ${ }^{1}$. Iznosim pretpostavku o jeziku u Podravini prije migracija, govorim o nastanku sela te prikazujem glavne osobine govora. Osvrćem se i na susjedne govore.
\end{abstract}

\section{A. Jezični odnosi u Podravini}

Važno je pitanje kakvi su odnosi, stanje, bili sjeverno od Podravine prije dolaska Mađara krajem 9. st., koji su prekinuli slavenski jezični kontinuum u Panoniji, gdje je razgraničenje bilo između zapadnoslavenske i južnoslavenske skupine. Gdje je bila granica kajkavštine, jer od 11. st. možemo već govoriti o kajkavštini kao posebnoj južnoslavenskoj jezičnoj jedinici, a u 12. st. već su u osnovi formirana naša narječja? Mogu li se u Podravini odrediti rasprostiranja i manjih jedinica od narječja - dijalekata - u predmigracijsko vrijeme, jer u 14 .

1 Ovaj je rad sufinancirala Hrvatska zaklada za znanost projektom [8706]. Tekst je pripremljen uz pomoć sustava za korištenje znakova ZRCola (http://zrcola.zrc-sazu.si) koji je u Znanstvenoistraživačkom centru SAZU u Ljubljani (http://www.zrc-sazu.si) razvio Petar Weiss. 
st. imamo u osnovi formirane već sve hrvatske, kao i druge srednjojužnoslavenske dijalekte koji i danas postoje (Ivić 1958: 61 ff, Lončarić 1990.)

Nakon dolaska Južnih Slavena stvoren je u Panoniji neprekinut slavenski jezični kontinuum. U njemu nije bilo izrazitih granica između Južnih i Zapadnih Slavena, a prekidaju ga svojim dolaskom Mađari. Kakav je bio jezik na području današnje Mađarske, tj. je li bio južnoslavenski ili zapadnoslavenski? Jezični dokazi govore u prilog južne hipoteze, točnije da je najveći dio toga područja bio južnoslavenski, a samo manji sjeverni, zapadnoslavenski. Posebno mjesto zauzimaju srednjoslovački govori, koje karakteriziraju znatne južnoslavenske crte (Krajčovič 1974: 21 ff). Zbog suživota Mađara i Slavena u istoj državi došlo je do uzajamne interferencije, utjecaja jednog jezika na drugi; mađarski je jezik preuzeo riječi za neke osnovne pojmove svakodnevnoga života (stol, prozor, dani u tjednu itd.).

Kakva je južnoslavenska jedinica, idiom, u to vrijeme bila na našem području? Bila je to prakajkavština, ona je u Podravini autohtona. Kada se može govoriti o kajkavštini kao posebnoj jezičnoj jedinici? Prije dolaska Mađara govori se o zapadnoslavenskoj i južnoslavenskoj skupini jezika, o južnoslavenskom prajeziku. Može se govoriti o dva južnoslavenska prajezika: istočnom - iz kojega se razvijaju bugarski i makedonski jezik, te o zapadnom - iz kojeg su se razvili srednjojužnoslavenski jezici (hrvatski, srpski, bošnjački i crnogorski jezik) te slovenski jezik. U 10. st. odvijaju se veoma važne promjene u slavenskim jezicima, pa tako i u zapadnom južnoslavenskom prajeziku. Tada se odvaja slovenski jezik svojim specifičnim razvojem od ostaloga dijela južnoslavenskog zapada, upravo od srednjojužnoslavenskoga prajezika. Međutim, veoma je važno da se približno oko toga vremena izdvaja i kajkavština kao posebna jedinica u hrvatskom jeziku i srednjojužnoslavenskom dijasistemu. Ona se svojim specifičnim razvojem, upravo svojom osnovnom akcentuacijom, odvaja od zapadne štokavštine i šćakavštine te čakavštine. Zapadna štokavština, koje su stariji oblici sačuvani u staroštokavskim slavonskim govorima te u istočnobosanskom ijekavsko-šćakavskom dijalektu, bila je jedna od pet pretpostavljenih (pra)jedinica srednjojužnoslavenskoga dijasistema. (Brozović 1963: 45 ff). U razvoju je do velikih migracija od 16. st. stajala između čakavštine i kajkavštine na jednoj strani, te istočne štokavštine na drugoj strani. Prodiranjem istočne štokavštine, s novoštokavskim razvojem, na područje zapadne štokavštine, dvije se štokavštine približavaju i razvojem jedna drugoj, tako da tu imamo rjeđi primjer razvoja - konvergentan, a ne divergentan.

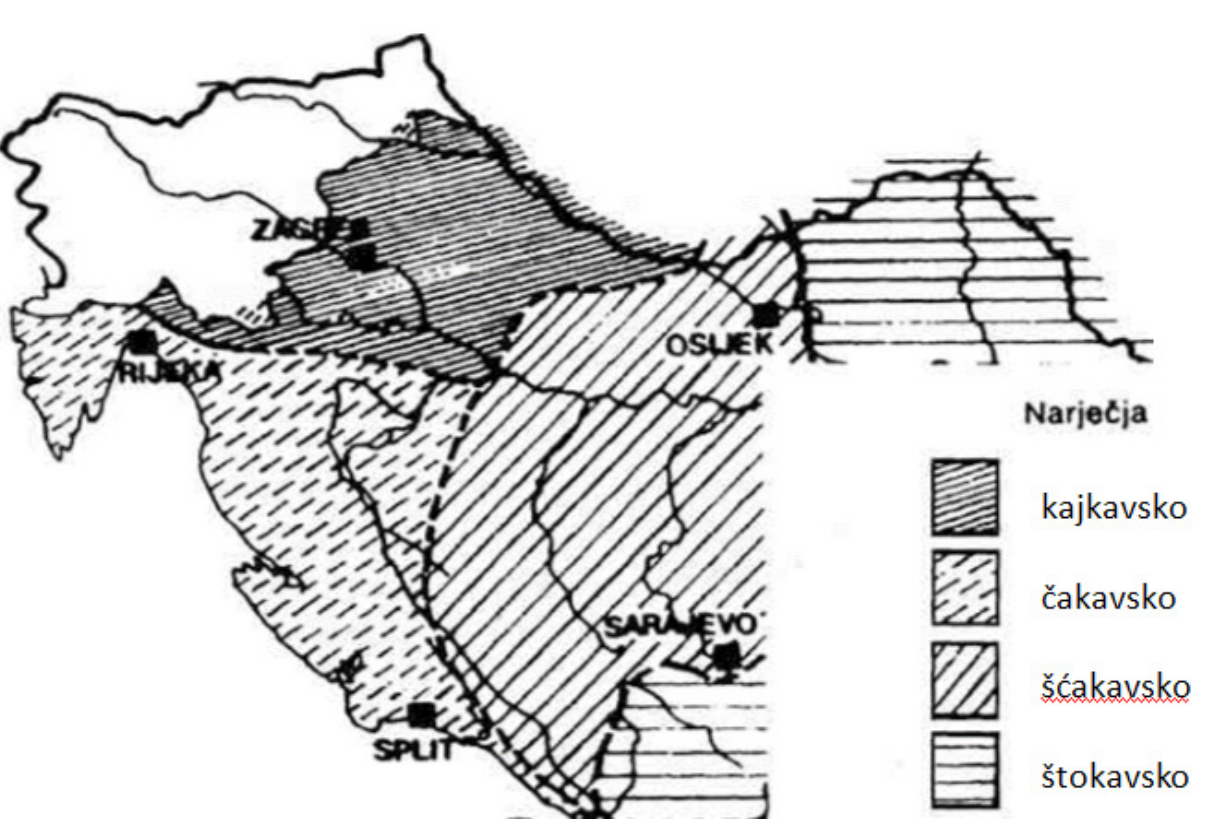

Vjerojatan predmigracijski raspored narječja (Lončarić 1988: 95)

Može li se govoriti o granici između kajkavštine i zapadne šćakavštine? O tome se zaključuje na temelju zapisanih imena mjesta. Nakon njihove analize, zaključio sam da je kajkavština, odnosno razvoj u kajkavskom smjeru na jugu Slavonije, u Posavini i u slavonskom središnjem dijelu, sigurno dosezao do Požeškoga gorja. Za slavonsku Podravinu valja pretpostaviti da je kajkavština na istok sezala najmanje do kraja oko Podravske Slatine (Pavičić 1953: 168 ff).

Granice u nekom jeziku, njegovu jezičnom kontinuitetu, nisu oštre, skokovite, osim ako ne postoje i velike prirodne granice, barijere (more, veće jezero, neprohodne planine i sl.). Kako toga u Podravini, osim Drave, nema, a takvom se jačom prirodnom granicom može smatrati Požeško gorje, na slavonskom sjeveru kajkavsko-štokavska granica nije mogla biti jače izražena. Treba pretpostaviti da nakon područja za koje sigurno možemo tvrditi da je bilo kajkavsko, nije bilo odmah posve nešto drugo, drukčije. Iza kajkavskoga područja dolazio je prostor koji su zauzimali prijelazni kajkavsko-zapadnoštokavski (šćakavski) govori, koji su na zapadu, bliže kajkavštini, bili više kajkavski, a dalje na istok sve manje kajkavski, a sve više zapadnoštokavski, šćakavski.

Katkad se jezične granice poklapaju i s političkim granicama. Poklapa se navedena jezična kajkavska granica u Slavoniji s granicom srednjovjekovne 
političke organizacije, prema karti N. Klaić (Klaić 1971), odnosno s kasnijom granicom Zagrebačke biskupije i Križevačke županije. U Podravini (u užem smislu) veoma je zanimljivo još jedno poklapanje političke i jezične granice. $U$ Podravini od Koprivnice do Kalinovca i Ferdinandovca te između Drave i Bilogore prostiru se govori s jedinstvenom akcentuacijom u slavenskom svijetu. To je akcentuacija u kojoj mogu biti naglašena samo posljednja dva sloga (naglasne) riječi, npr. lastavica, lastavice $\grave{e}^{2}$ (Ivšić 1936). Područje njezina prostiranja, narušeno migracijama za turskog prodora, poklapa se uglavnom s prostiranjem stare komarničke županije, odnosno s kasnijim vlastelinstvima (đurđevačkim i dr.), koji su je naslijedili (Lončarić 1978).

Kajkavsko narječje na istoku i jugoistoku prelazi u štokavštinu, na jugozapadu u čakavštinu, a na zapadu graniči sa slovenskim jezikom.

U koprivničkoj Podravini prolazi najvažnija granica u kajkavskom dijasistemu, i to od Drave, sjeverno od Koprivnice, preko samoga grada na Kalnik, a otuda dalje prema Medvednici, do rijeke Zeline; Zelinom skreće na jug, do utoka te rijeke u Lonju, odnosno do Ivanić-Grada, a zatim dalje na istok, na Moslavačku goru (Ivšić 1936). U Podravini sjeverno i zapadno od te crte prostiru se tzv. konzervativni kajkavski govori, koji najbolje čuvaju starinu u akcentuaciji. Na istoku, točnije na sjeveroistoku kajkavskoga područja, nalaze se njezini revolucionarni govori s obzirom na naglasak, upravo dvije takve skupine govora. Jednu skupinu (nazvao sam ju podravskim dijalektom) čine spominjani govori s ograničenim mjestom naglaska na posljednja dva sloga riječi. Druga je, mnogo veća skupina, koja zauzima najveći dio sjeveroistočne kajkavštine, skupina također s vrlo važnom osobinom u slavenskim jezicima (osobinom koja je vrlo slična crti koju nalazimo u litavskom jeziku), a to je unakrsna metatonija, promjena tona (uzlazno - silazno), i to cirkumfleksa (dugosilazni naglasak) i akuta (dugouzlazni naglasak), npr. mêso $>$ mẽso, sũ̌sa $>$ sûša. U tome je specifičan rečki kajkavski govor.

Nove dijalektne granice uvjetovane su iseljavanjem starosjedilačkoga stanovništva za turskog prodiranja polovicom 16. st. i doseljavanjem novoga stanovništva s jugoistoka Bosne (ijekavsko-šćakavski govori kod Virovitice i u Reki, ikavsko-jekavski govor Virovitice) i istočne Hercegovine (većina novoštokavskih govora). Dalje, nakon odlaska Turaka (kraj 17. st.) naseljavanje je iz suprotnoga smjera, tj. sa zapada dolaze kajkavci, među kojima ima sigurno i

Služim se transkripcijom prihvaćenom za Hrvatski jezični atlas, tj. hrvatskom tradicionalnom dijalektološkom transkripcijom, a gdje ona nije dovoljno dobra (npr. znak za naglasak gdje nema opreke po modulaciji, tonu) uzeta su rješenja iz API-ja (međunarodne fonetske transkripcije). potomaka prije iseljenoga stanovništva. Miješanjem raznih kajkavskih govornih tipova međusobno i sa štokavskim govorima nastaju novi govorni tipovi. Vojna krajina nije značajnije utjecala na jezične granice. Današnje stanje vidi na dijelu mape Karta sjeveroistočnih kajkavskih govora (Lončarić 1981).

\section{Gradski govor}

Gradski govor Koprivnice formirao se kao interdijalekt, rezultanta različitih dijalekata svoje okolice - triju kajkavskih i novoštokavskoga, s jedne strane, te pod utjecajem književnoga jezika. Utjecaj kajkavskoga književnog jezika bio je sigurno veoma jak, jer je i on bio dobrim dijelom po svojoj strukturi i leksiku rezultanta više kajkavskih tipova, dijalekata. Novi književni jezik nakon 1835. bio je drugoga tipa (Lončarić 2009).

Danas u Koprivnici, kao i obično u gradovima, treba razlikovati dva sredstva, dva idioma općegradske komunikacije. Jedno je koprivnička varijanta kolokvijalnoga, razgovornoga stila hrvatskoga književnog jezika, koja je podtip zagrebačke varijante, kao što su to i križevačka, varaždinska i krapinska varijanta. Drugo je koprivnički kajkavski koine, interdijalekt, koprivnička kajkavština. Može se govoriti o još jednom idiomu slične funkcije, a to je koprivnička štokavština, koju ne smijemo brkati s koprivničkom podvarijantom kolokvijalnoga, govornoga stila književnoga jezika, iako mu je bliska. To je slično, u manjem obimu, zagrebačkoj situaciji, gdje također imamo, uz idiom kolokvijalnoga stila, i zagrebačku štokavštinu. Koprivničkom štokavštinom, kao i zagrebačkom, govore građani kojima je materinski idiom štokavština, u Koprivnici upravo novoštokavština.

\section{B. Rečki govori}

U Reki tri su vrste govora - kajkavski, s tri varijante, i dva štokavska. Većina Hrvata govori ili je govorila kajkavski, a manji dio govorio je istočnobosanskim ijekavsko-šćakavskim, kao dosta sela oko Virovitice, porijeklom iz istočne Bosne. Srbi govore novoštokavskom ijekavštinom (moglo bi se reći i novoštakavskom, jer je zamjenica šta), istočnohercegovačkim dijalektom. Za osnovni kajkavski govor Reke uzimam govor koji se govorio u mojem djetinjstvu, prije 60-70 godina, kada je selo bilo selo i kada je mjesni govor bio glavno sredstvo društvene komunikacije, prije velikih civilizacijskih promjena nakon II. svjetskoga rata. I tu već moramo utvrditi da su i tada postojala u selu dva tipa kajkavštine, jedan u Staroj, drugi u Novoj Reki. Koje je porijeklo kajkavštine u Reki i kakav je njezin razvoj? (Lončarić 1996) 
Dok za štokavske idiome nije teško odrediti porijeklo i razvoj, za kajkavski to nije tako jednostavno. I danas je dosta komplicirano utvrditi govor sela, $i$ to zato jer se osnovni govor mijenja pod utjecajem književnoga jezika, školovanjem, radom izvan mjesta, agresijom javnih medija, blizinom grada, s jedne strane, te doseljavanjem novih kajkavaca iz različitih područja, tako iz Zagorja, kalničkoga prigorja i dr. Jezik se mijenjao više u jednom desetljeću nego prije u jednom stoljeću. Posebno se razvio govor na Rečkom polju.

Selo je nastalo relativno kasno, vjerojatno u drugoj polovici 16., najkasnije u prvoj polovici 17. stoljeća. Prvi put se Reka spominje u kanonskoj vizitaciji Komarničkog arhiđakonata (sjedište u Komarnici, danas Novigrad Podravski) za 1671. godinu. Koja su sela postojala u njezinoj blizini, prije dolaska štokavaca, od 16. st.? Područje je pripadalo koprivničkom vlastelinstvu, koje je u 14. st. bilo dio kotara Komarnica. Južno od njega bila je (mala) županija Rovišće. Kasnije je na sjeveru od Reke bilo rasinjsko vlastelinstvo; granica je vjerojatno išla šumom po Dugom brdu. Južno je bilo đurđevačko vlastelinstvo, a na zapadu je kalnički kotar.

Ako idemo od juga, sela su bila: Jagnjedovec (i danas); Kameno (danas postoji Kamenica, malo selo); istočno od Reke je Podkameno (danas Stari grad); Pribislavec (između Podkamena i Koprivnice, danas ga nema). Na sjeveru su bile Kochane (vjerojatno danas područje Kučine); Mučna (danas Rečko domaje), a istočno od nje, prema Koprivnici, Kaznetine. Zapadno su bila sela Bankovec, Hermanovec Presečno (nisu točno locirana, danas ne postoje, tu su sada sela Velika Mučna, Grdak, Sokolovac (prije Kukavica.) Na Bilogori, južno i jugozapadno područje pripadalo je topolovečkom vlastelinstvu.

Imanje Powsahegh-Povšaheđ (zapisano i kao Posahegh i Posahecz, u prijevodu: Povšin brijeg ili Povšino brdo) spominje se na izmaku srednjeg vijeka. Imanje je zapisivano nakon Glogovnice, Gragene, a prije Sesveta, Gornje Blizne (Bliznafew). Vjerojatno je posjed bio na prostoru današnjih sela Mali Poganac, Botinovac, Mali Grabičani, Prnjavor i Grdak te na sjeveru međašio s imanjem Herbortija na potoku Gliboki (Rasinja) (Pavleš 2001).

Toponim Bradna sačuvan je u imenima sela Mala i Velika Branjska. Ime sela Ladislav nastalo je po nestaloj crkvi Svetog Ladislava. Imanje Bradna pružalo se od Male preko Velike Branjske do spomenutog sela Ladislav. Budući da je imalo priličan broj poreznih dimova, može se također pretpostaviti da je zahvaćalo i prostore današnjih sela Miličani i Srijem, dok je dalje na istok vjerojatno međašilo s rovišćanskim vlastelinstvom. Na sjeveru je imanje dolazilo blizu potoka Koprivnice, a na zapadu do Velikih Sesveta (posjed Bliznafew)

\section{KARTA SJEVEROISTOČNIH KAJKAVSKIH GOVORA}

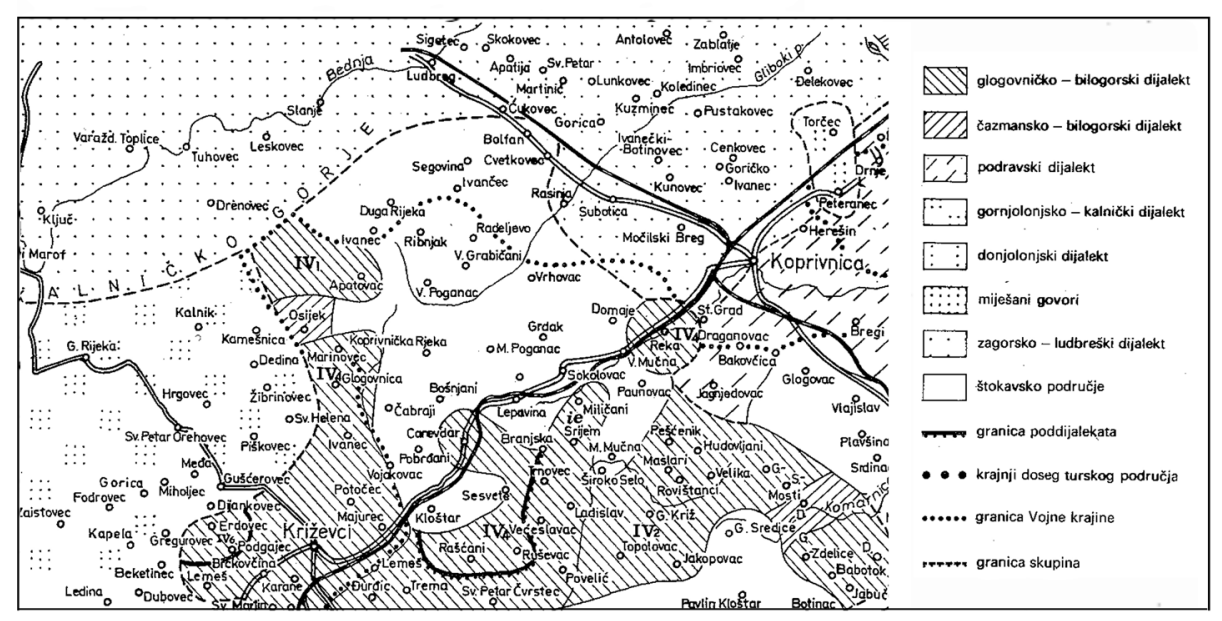

i Većeslavca, koji su u srednjem vijeku bili posebni posjedi. Imanje Bliznafew (zapisivan i kao Byznafew i Blyzafew) ili Gornja Blizna pružalo se na području Velikih Sesveta i na sjeveru dodirivalo potok Koprivnicu kod Lepavine. Dio posjeda se najvjerojatnije nazivao i Sesvete po titularu župne crkve.

Može se pretpostaviti da je Reka komunicirala s obližnjim selima na koprivničkom vlastelinstvu, zatim s najbližima na zapadu, na posjedu Powsahegh, gdje su danas sela Mali Poganac, Botinovac, Mali Grabičani, Prnjavor i Grdak i zatim s posjeda Bradna. Važna su mjesta, zbog veličine, Podkameno (75 dimova), Kameno (8) - na istoku, te Mučna (14) i Kaznetine (8) - na sjeveru; slijedi Powsahegh (nema podataka o veličini).

Može se pretpostaviti da su ta sela prije migracija imala više-manje isti govor. Sudeći po današnjem stanju, i sela na Bilogori imala su sličan govor. Reke još nije bilo.

Novopridošli štokavci naseljuju se u stara mjesta, tako u Mučnu i posjed Powsahegh. Kada u 17. st. počinje seljenje na važnije prometnice i nastaje Reka (najprije Stara), većinom od stanovništva Mučne i okolice, dolaze i kajkavci i štokavci (Hrvati i Srbi). Kajkavci donose svoj stari idiom, ali su već stoljeće prije živjeli sa štokavcima, tako da je dolazilo do interferencije, utjecaja novoštokavštine, koja se nastavlja na novom mjestu, i bila je znatno jaka. Ona je olakšana time što je i dio katolika novoštokavaca (istočnobosanski ijekavsko-šćakavski dijalekt). 


\section{I. Štokavski govori}

Prva skupina doseljenika uskoka došla je na Bilogoru 1540. god., i to iz Kranjske i Žumberka, pa je teže odrediti otkuda zapravo potječu. Dvije godine kasnije nalazimo uskoke u današnjem Virju, Strezi (Pavlin Kloštru), a 1544. godine ima ih u Ivaniću, Gradecu, Ludbregu, Križevcima, Topolovcu i Koprivnici, gdje danas nema starih štokavaca. Doseljenici se nazivaju Vlasi-Walachen. Velik dio potomaka toga stanovništva jesu Hrvati, naročito u bjelovarskom kraju, koji sebe nazivaju šokcima (Porijeklo naziva šokac \| šokec, šokci još nije razjašnjeno. Rem 1993).

$\mathrm{Na}$ istoku novoštokavskoga ijekavskoga područja, kao i istočno od Neretve, otkuda stanovništvo potječe, ima i danas Hrvata katolika koji su novoštokavci ijekavci. Zanimljivo je da pravi Podravci, između Bilogore i Drave, nazivaju i danas Bilogorce, bez obzira jesu li Srbi ili Hrvati, pa čak ako i nisu štokavci - Vlaji.

Veliku većinu mjesta na tom području koja danas postoje nalazimo na početku 18. st. U popisima susrećemo i neka mjesta koja sada ne postoje. Sela su okupljena u vojvodstva. Obično u neko vojvodstvo ulaze sela koja međusobno graniče, ali ima vojvodstava neobična sastava. Tako su vojvodstvo Bansona činila sela koja su veoma udaljena jedno od drugoga: Rovište, između Bjelovara i Križevaca, Šandrovec, između Bjelovara i Novigrada Podravskoga, i Miličani, između Koprivnice i Križevaca. Rovište je štokavsko, a Miličani i Šandrovec imaju kajkavske govore koji se dosta razlikuju međusobno. Broj sela u vojvodstvima kreće se obično oko deset. Naravno, i u novim kapetanijama dolaze skupa štokavska i kajkavska, i to raznorodna kajkavska mjesta.

Područje je štokavštine na kalničko-bilogorskom zemljištu dviju vrsta. Jedno je nastavak kompaktne štokavske cjeline iz Slavonije, koja kao poluotok seže jednim svojim krakom na sjeveru na dvadesetak kilometara od Koprivnice, a na zapadu petnaestak km od Vrbovca. Drugo su dva otoka, jedan veći između Koprivnice, Križevaca i Ludbrega, drugi manji, između Koprivnice i Novigrada, te nekoliko otočića od po jednoga sela, odnosno zaseoka. Manji štokavski otok obuhvaća sela Javorovac, Srdinac, Plavšinac, Delove i Jeduševac (zadnja dva sela većinom kajkavska), Vlajslav, Glogovac, Borovljane i Gornju Bakovčicu (Drugu i Treću).

U većem otoku počevši s istoka, od Koprivnice, prvo je selo Reka (i kajkavski), zatim Velika Mučna, Sokolovac i Lepavina. Na bilogorskom su području Široko Selo, Mala Mučna, Srijem (i kajkavski), Paunovac (Panovljani), Mala
Branjska, Sesvete (Male), Vojakovački Kloštar. Na kalničkom području ova sela graniče s kajkavskim selima: Bošnjani, Vojakovac, Ivanec, Čabraji, Koprivnička Rijeka (Rečica), Veliki Poganac, Duga Rijeka, Segovina te Ćukovec i Bolfan, u kojima se govori i kajkavski.

Naseljavanje pustoga zemljišta počelo je nakon oslobođenja Slavonije, krajem sedamnaestoga stoljeća. Posljedica je naseljavanja sa zapada na istok u postepenom redu bila i ta da su istočnija sela dobivala nove koloniste i iz zapadnijih već nastanjenih mjesta. Potomci su doseljenika u Reku kajkavci i štokavci, a u Mučni samo štokavci. Staro napušteno zemljište naziva se Rečko domaje. S obzirom na količinu kajkavskoga utjecaja, moglo bi se govoriti o četiri, odnosno pet stupnjeva i o toliko skupina govora (Lončarić 2007).

Uz prikaz štokavštine u Reki, osvrćem se nešto i na novoštokavštinu okolnoga područja u Koprivničko-križevačkoj županiji, nekadašnjem Varaždinskom generalatu u Vojnoj krajini, kako bi se vidio položaj rečkih štokavaca među ostalim štokavskim govorima (Kašić 1963).

\section{Fonologija}

a) Naglasni sustav

U većini govora naglasni je sustav u osnovi jednak, postoje manje razlike između njih. Ti govori imaju četveroakcenatsku novoštokavsku akcentuaciju, sa specifičnom podjelom naglasaka na slogovima riječi. Oni imaju dva kratka akcenta, koji se kao i dugi razlikuju po modulaciji, kretanju tona (uzlazno - silazno). Dakle, dva su kratka i dva duga naglaska, dva uzlazna i dva silazna (kao u književnom jeziku): kratkosilazni ( "), kratkouzlazni ( '), dugosilazni ( -) i dugouzlazni ( $\left.{ }^{\prime}\right)$. Specifična je raspodjela naglaska u tome što svi naglasci mogu stajati na svakom slogu riječi (obično uzlazni naglasci ne dolaze u zadnjem (i jedinom) slogu, a u našim govorima tu dolaze i kratki i dugi uzlazni naglasci). Silazni naglasci u zadnjem slogu rjeđi su nego uzlazni (dolaze većinom u stranim i ekspresivnim riječima). Sustavi pojedinih govora razlikuju se posebno po nenaglašenoj, zanaglasnoj duljini. Jedni govori imaju nenaglašenu duljinu u svim položajima, i u zadnjem otvorenom slogu. Nenaglašenu duljinu nemaju Hrvati i dio Srba u Reki i nekim drugim mjestima, što je kajkavski utjecaj. Uz te akcente prozodemi su još kratak i dug nenaglašeni slog. To odgovara inventaru standardnoga jezika. 
Inventar naglasaka

\begin{tabular}{|l|c|c|}
\hline & \multicolumn{1}{|c|}{ silazni } & uzlazni \\
\hline kratki & " & , \\
\hline dugi & $\frown$ &, \\
\hline
\end{tabular}

Primjeri s minimalnim parovima, koji pokazuju fonologičnost prozodijskih obilježja potvrđeni u Reki, u kajkavskom i štokavskim govorima, a tako je i u drugim štokavskim i nekim kajkavskim govorima:

sëla 'sjela'-sèla G jd. od sèlo

kûma $\mathrm{G}$ jd. od kûm - kúma $\mathrm{N}$ jd. 'kuma'; pêta broj-péta $\mathrm{N}$ jd. 'peta' vôz 'kola' - vòs (se) imp. od vòzit 'vozi (se)',

nôs (organ) - nòs imp. od nòsit 'nosi'

ròdi 3. jd. od 'roditi' - ródi $\mathrm{D} \mathrm{jd}$. od 'roda'; bòst inf., bòd imp.

rôd 'rod' - ròd imp. od ròdit 'rodi'

donès 'donesi' küp, stär imp., čùp; brät $\mathrm{N}$ jd. 'brat' i inf. 'brati', pëko 'pekao'

mlâda 'nevjesta' - mláda pridj.

podiél 'podijeli', podiélt 'podijeliti'

preslóšt inf., preslóž imp. 'presložiti'; povúć, povúc, vúkla

zamàsla, preslàtka, rešèta; staláža, okrúgo.

Dugosilazni naglasak rijedak je u sredini riječi, npr. obiêdovat, prejâko, rafangiêrač. Na zadnjem slogu dugosilazni je naglasak običniji, a može stajati i kratkosilazni, npr. veterinâr, živinâr, preskûp; presläb, zafrkänt, komandänt, reštänt.

Dublete. Pojedine se riječi, odnosno pojedini oblici, pojavljuju s dva naglaska, postoje naglasne dublete, npr. gòri || góri 3. jd. od góret || gòret 'gorjeti', rùbača \| rübača, pònava - pońáva, òtava - otáva.

Važno je pitanje jesu li novoštokavski uzlazni naglasci jednosložni ili dvosložni. Moguće je i jedno i drugo u različitim govorima. I sâm sam kod govornika različitih novoštokavskih govora imao prilike ustvrditi najmanje dva izgovora uzlaznih naglasaka, jedan ,jednosložan” i jedan „dvosložan”, ali i treći.
Naveo bih još jednu činjenicu koja gotovo da je bila nepoznata a nikako nije bila uključena u raspravu o prirodi naglasaka. Riječ je o tome da u jednom dijelu novoštokavskih govora uzlazni naglasci mogu stajati i na zadnjem i na jedinom slogu (Ivšić: u Slavoniji i Dalmaciji, kod Bjelovara, a meni je poznata iz virovitičkog, koprivničkog i križevačkog područja). Jasno je da u tim govorima uzlazni naglasci ne mogu biti dvosložni jer kada su ti naglasci u zadnjem, odnosno jedinom slogu - drugoga sloga nema. A nije vjerojatno da se uzlazni naglasci u nezadnjem slogu izgovaraju bitno drukčije. Može se tome staviti prigovor da to nije tako u standardnom jeziku, što je istina samo za birani jezik, dok u razgovornom stilu dolazi.

Glagolske i zamjeničke klitike, riječi bez svojega naglaska - nenaglasnice mogu biti enklitike, zanaglasnice, i proklitike, prednaglasnice. Prijedlozi i veznici samo su prednaglasnice. Prenošenje naglaska na proklitiku, prednaglasnicu nije rijetko. Na glagolske i zamjeničke proklitike ne prelazi naglasak s riječi na koju se naslanjaju. Preneseni naglasak ima i jednu od dviju modulacija tona, uzlaznu ili silaznu, kao i u književnom jeziku.

Zamjeničke klitike: pòslo-te štok. || pòslal-te kajk. - te-pòslo || te-pòslal, pöjo-ga || pöjel-ga-ga-pöjo || ga-pöjel. Prijedlozi uz naglašene oblike tih zamjenica sa silaznim naglascima dobivaju kratkosilazni naglasak (uz dubletu bez prijelaza): bëz-ńi , zä -nas, prëd-ńega uz bez-ńî, pred-nâs, pred-ńèga. U svezi s kraćim, nenaglašenim oblicima ličnih zamjenica za akuzativ, prijedlozi imaju dugouzlazni naglasak (kao i u standardnom jeziku): zá-me; préd-ńu.

Glagolske klitike: dōšo-sam štok. || döšel-sem kajk. - sam-dǒšo || sem-döšel; vïdjeli-ga || vïdli-ga-ga-vïdjeli || ga-vïdli. U glagola silazni naglasci s prvoga sloga prelaze na negaciju, npr. nè-vidim, kao prè-vidim - vîdim, nè-kopam kao zàkopam - kopam, ali zamästil. Naglasak je na negaciji uzlazan. Posebnosti: nè-damo - dámo, nè-smeimo - smeímo; në-bumo - bùmo, në-znamo - známo.

$\mathrm{S}$ ostalih vrsta riječi naglasak se redovno ne prenosi, npr. za-krävu, naögradu (ali Pòdograda, ime polja, rudine), za-mârvu, od-stârca. U nekim primjerima imamo prenošenje, i to dvovrsno. U jednim slučajevima proklitike dobivaju kratkouzlazni naglasak, kao i pri pomicanju naglaska u okviru riječi (Pòdograda): pòd-stol - pod-stöl, nà-dvor uz na-dvôr, nà-leto - na-lëto; samo je nà-pašu. U drugim (kada silazni naglasak riječi odgovara starom silaznom naglasku) na prednaglasnici je kratkosilazni akcent.

S obzirom na dijakroniju, na porijeklo naglasaka u pojedinim kategorijama riječi, oblicima, odnosno s obzirom na raspodjelu, karakteristično je nekoliko kategorija, npr. infinitivni likovi tipa dóć, náć, pèć. 


\section{b) Vokalizam}

Svi su govori ijekavski. Nije svuda jasno je li riječ o peteročlanom vokaliz$\mathrm{mu}(i, e, a, o, u)$, gdje na mjestu dugoga jata imamo tzv. dvosložnu zamjenu / ije/, ili imamo šesteročlani vokalizam, gdje je šesti vokalski fonem bio dvoglas / ie/ na mjestu dugoga jata. Susreće se i jedan i drugi izgovor, i to kod istih informanata, npr. diéte || dijéte, siêno || sijêno, biéla || bijéla. U kratkim slogovima na mjestu kratkoga jata redovno dolazi je, npr. djèteta, vjènčić, bjelìna, s malo izuzetaka. Prema sekundarnom dugom jatu u sufiksu dolazi ije ||ie, npr. tòčier \| tòčijer 'lijevak'. Ispred $j$ te $o$ dobiveno je $i$, npr. grïjat, pòndiljak, grî(j), gri(j)òta (sa starijom zamjenom spiranta $x$ ). Govori se jëo || ïjo, sjëo \|| sïjo, srëo || srïjo.

U nekim kategorijama došlo je do ispadanja zanaglasnih, starih kratkih vokala $i$, rjeđe $u$, različito u pojedinim govorima. Deset je kategorija u kojima ispada $i$, npr. množinski padeži na -ima (kölma || kölima, vràtma || vràtima, foringášma $\|$ foringáśima), u pridjevu radnom (kúpla, kúplo, kúpli, prema kúpil), u tvorbenim sufiksima -ina, -ica, -ić (gödna, krävca, gràpća 'grabića') te uopće u višesložnih riječi (jäpka/<jäbuka/, zòpka /< zòbuka/). Rjeđe je otpadanje nastavka -i za N mn. m. roda u imenica i pridjevu radnom, npr. prema selják(-s) pjëval dolazi i seljáki(-su) pjëvali. Najviše kategorija obuhvaćeno ispadanjem je u potkalničkim govorima. Manje ga je u govoru Hrvata štokavaca.

Sažimanjem skupa ao dobiveno je $o$, npr. rëko, pläko, sónce 'saonice', ali glagoli II. vrste (književno sa $n u$ ) imaju u infinitivu sufiks sa $i$, npr. dìgnit, màknit, prema 'dignuti, maknuti'. Kajkavski govori sa štokavskim utjecajem imaju tako, u Reki i drugdje. Redovno je èdan ‘jedan', èsam ‘jesam’ itd., ispred $e$ nema $j$.

Zijev se većinom uklanja, i to sa v, npr. ötevo, čüvo, žëvo, pöčevo, ïzuvo. Sa $j, v$ uklanja se zijev na mjestu staroga spiranta $x$, ono je zamijenjeno većinom sa $v$, npr. üvo, bùva, öčuv, a j dolazi uz prednje vokale, npr. màcija, grijòta, grî(j). U snàja, uz snâ, i òraj tako je zbog staroga poluglasa, što znači da je nestanak $x$ vrlo stara pojava, da nestaje prije prijelaza poluglasa $\mathrm{u} a$.

\section{c) Konsonantizam}

Većina govora ima dva para palatalnih afrikata: $\check{c}-\dot{c}, \check{\zeta}-\dot{\zeta}$, odnosno $\check{c}-\check{\zeta}, \dot{c}$ - ź, i jednu nepalatalnu (c). Svi srpski govori na kalničko-bilogorskom području imaju tako, kao i većina hrvatskih štokavskih govora. Hrvati u Križevačkom Ivancu, Žabnu, na bjelovarskom području imaju samo jedan par palatalnih afrikata, srednje $(\breve{c}-\breve{\zeta})$, a neki imaju i par nepalatalnih: $c-3(d z)$, što je kajkavski utjecaj. U Reki štokavci imaju 3, npr. bèzga, bèzgovna; riječ zòpka, zòbuka postoji pasivno u starijih ljudi.

Spirant $x$ dolazi samo $\mathrm{u}$ onih govora koji su pod utjecajem kajkavskoga.

U nekim se govorima uz slogotvorno $r$ pojavilo i slogotvorno $n$, npr. dignt, käpnt. Konsonantizam ovih govora ima duge suglasnike, koji su nastali otpadanjem samoglasnika, npr. slànna $(<$ slànina), mòlla $(<$ mòlila), (môram) plàtt (uz plàtit) inf., prema (däj) plàt imperativ. Mogu se smatrati dvostrukim suglasnicima, kao dva ista suglasnika, tako ih pišem.

Negdje je ukinuta opreka između mekoga i tvrdog laterala: $l=l$, ispred visokih, prednjih samoglasnika dolazi samo meki, kao i u susjednim kajkavskim govorima, npr. möl̦im (< mölim), (òne su) zéle zêl̦e 'uzele zelje'.

Izostaju rezultati sibilarizacije, II. palatalizacije u imenica, $\mathrm{tj}$. generalizirana je ista osnova riječi u padežima, nema zamjene u osnovi $(k\|c, g\| z, x \| s)$ npr. čvárki, rúk(i), nòg(i), a ne čvárci, ruci, nozi.

Najnovije jotovanje je ograničeno. Dosljedno su jotirani samo $n, t$, npr. grâne 'granje', prûće, a drugi suglasnici u nekoliko riječi. Redovno je źëd $(<$ djed), ̧́ë (</g/dje), nèźḷla (književno pismo: đed, đe, neđelja). Ima dubleta, npr. ćërat, požúćet; śütra; ćëta 'cvjeta', ćèdlo 'cjedilo'. Svuda je nëtjak, odnosno mëtjak (u potkalničkom kraju). Negdje je ispalo v: jëverca (M. Poganac), sjèdok (Sokolovac). Svuda je crëšńa, ako nije preuzet kajkavski oblik kao čeréšńa u Ivancu. U Osijeku Vojakovačkom jest bäuk za 'pauk'. U šćakavskom govoru samo je nàmješćen, púśćat, ögńišće, a u,štakavskom” i nàmješten, púštat, ögńište. Redovno je óćla 'otišla'. Krajnje 1 prešlo je u $o$, uz odstupanja; dolazi stöl, völ - stô, vô; kïsel, dèbel, vësel. U pridjevu radnom, m. jd., također je bilo tako, ali je to $o$ uz neke vokale dalo sažeto dugo $o$, koje je u nenaglašenom položaju skraćeno: bïo; vòzjo, lètjo; do, stô; rëko, näšo, köpo. Obično je zamjenica kö, negdje, tkö, a redovno nëtko, nïtko.

\section{Morfologija}

Od morfoloških osobina važno je: gubitak imperfekta i aorista, kojemu se čuvaju tragovi, npr. u riječci rëko (ôn je, rëko, spläšen), u bi (döšla \|dòšli bi). Muški hipokoristici na -o sklanjaju se po e-deklinaciji, npr. Stévo, Péro - Stéve, Pére.

U G mn. pridjeva nastavci su -ija || -ije, a u ostalim padežima meke promjene; u Reki i Plavšincu samo je -ije; u Ivancu je -iju, npr. (pêt) vëlikija || vëlikije || vëlikiju (rástova). Izjednačeni su DLI mn., npr. (dájem) siromákima $\|$ siromákma - (razgòvaramo se o) siromákima \| siromákma - (razgòvaramo se 
sa) siromákima || siromákma. Karakterističan je nastavak u a-osnova-am, npr. sèstram, mäčkam, küćam; slúgam, koji dolazi i u nekim kajkavskim govorima, tako u Reki. U posvojnih pridjeva i I jd. i-deklinacije nastavci imaju $i$, koji obično ispada, npr. päsiji || päsji, kr̀vijom || kr̀vjom; u Reki je kr̀vılom.

Nekoliko je izuzetnih pojedinačnih oblika, tako G mn. od rúka, nòga glasi u Reki, Sokolovcu itd. rùkuva, nòguva; u Osijeku nòguja, rùkuva.

Obično je generaliziran nastavak - u u 3. mn. prezenta, tip (òni) râdu, mïslu, kao bèru; obično je i pèču, ne peku. U Osijeku i Sokolovcu 2. jd. imperativa 'jesti' glasi (dëj) ïje.

\section{Leksik}

Za leksik osim navedenih kajkavskih utjecaja (bezga...), navodim, zbog prostora, samo dvije osobitosti, za koje ne znam jesu li gdje drugdje zabilježene. Prvo, to je leksem za 'krumpir', koji je u nekim selima već izgubljen, a glasi rëpce. To je, dakle, autohton domaći naziv za novu poljoprivrednu kulturu, izveden od starije narodne riječi rëpa, deminucijom - rëpica 'mala repa'. Postoji šaljiva uzrečica: Ôš krumi(j)éra il rëpce? (Riječ krumpir je porijeklom od njemačkoga Grundbirne 'zemljana kruška'.) Druga je riječ vï̌́elo (< vidjelo). što znači 'svjetlo, svjetiljka', npr. Upál vï̌́elo.

\section{Zaključak}

Može se zaključiti da su u osnovi štokavskih govora na kalničko-bilogorskom području većinom govori iz iste matice. Bilo je, međutim, nosilaca štokavskih govora sa šireg novoštokavskoga područja, tako iz istočne Bosne. Čini se da su najbrojniji bili doseljenici, njihov govor, s gornjega toka Neretve, većinom Srbi, ali i Hrvati. Manje su bili prisutni govornici starih slavonskih kajkavsko-štokavskih govora. Živeći nekoliko stoljeća na okupu, odcijepljeni od svoje matice, ujednačava se novoštokavština ovoga područja, kao što Brozović pretpostavlja i za štokavštinu u cjelini. Javljaju se i inovacije koje su zajedničke tim govorima, a drugdje nisu tako proširene, npr. mjesto naglaska (Okuka 2008).

Zbog kontakta s kajkavskim govorima, različitoga opsega i jačih elemenata štokavskih govora iz različitih matica, javljaju se i neke nove, odnosno čuvaju neke starije razlike između pojedinih lokalnih govora. S obzirom na veličinu područja koje zauzimaju, kalničko-bilogorski štokavski govori međusobno se manje razlikuju nego što je to, na primjer, na Baniji i Kordunu.
Na kraju može se reći da se u Reki, kao i uopće na kalničko-bilogorskom području, kojemu možemo priključiti i moslavački čazmanski štokavski otok, formirao poseban tip ijekavske novoštokavštine, koji ima jedne osobine zajedničke s jednim novoštokavskim ijekavskim govorima, a druge s drugima, ali nigdje ne nalazimo baš takav inventar ili distribuciju. Prema tome, ti se govori ne izdvajaju nekom svojom posebnom crtom, ili crtama, već ukupnošću osobina. U nekima od njih, i to hrvatskim govorima, ima znatnih kajkavskih utjecaja, tako da možemo govoriti o štokavsko-kajkavskim govorima.

\section{Kajkavski govor}

Kakav je mogao biti osnovni kajkavski idiom, govor na tom području? Sigurno je bio onakav kakav susrećemo danas na obližnjoj Bilogori, odnosno vrlo sličan: ima tipičan stari kajkavski razvoj, kao većina kajkavskoga narječja, sve tri osnovne genetske kajkavske fonološke značajke:

a) osnovnu kajkavsku akcentuaciju; b) dva jednačenja u vokalizmu: i) jednačenje jata i poluglasa $(\partial=\breve{e})$, te ii) stražnjega nosnoga samoglasnika i slogovnoga $l(Q=l)$.

Po akcentuaciji to je bio tip s unakrsnom metatonijom dugih naglasaka (mêso > mẽso, sũša > sûša) i križnom metataksom kratkih naglaska (lòpata < lopáta, jagóda < jágoda). Imao je tri naglaska: dva duga, uzlazni i silazni, i jedan kratak. Vjerojatno je imao prednaglasnu duljinu. To su moja tri tipa A.a. Tip A.a.1. (Ivšićevi IV ${ }^{2}$ i IV ${ }^{4}$ ) danas je čest, od bližih sela nađen je na Bilogori (Reka: Prekogori) u Maslarcima, Peščeniku, Ladislavu, Čvrstecu, zatim Topolovcu i u udaljenijim mjestima, npr. Cirkvena, Mosti. Zadnji slog u načelu nije naglašen, nema nenaglašene duljine. Dalje se je razvijao pod utjecajem novoštokavske akcentuacije (Lončarić 1986).

Spomenuto je da se kajkavski Stare Reke dijelom razlikuje \| razlikovao od Nove, tako i u akcentuaciji, i to upravo kod te dvije pojave. Stara Reka ima u osnovi mẽso, a nova mêso (što je glavni znak raspoznavanja), zatim Stara ima jagòda $(<$ jagóda $<$ jágoda), nova jägoda $(<$ jágoda). Kako to protumačiti? Pretpostavljam da je stariji naglasak kajkavaca Nove Reke bio kao i Stare. To se može tvrditi na osnovi nekih izričaja u Novoj, koji su ostatak starijeg stanja; govori se u Novoj, npr. ìdemo po pútu, ali obično je idèmo spât || jêist. Interferencijom s novoštokavcima, sustavna je starija akcentuacija promijenjena (Lončarić 2013). 


\section{Fonologija}

a) Naglasni sustav

Kajkavski govor u Reki ima novoštokavski inventar (moj tip A.a.1.), uz dva duga ima i dva kratka naglaska, npr. sèla $\mathrm{G}$ jd. (od selo) - sëla 'sjela', žène se žëne, lòpata - jägoda, zèmlja - zëmlju. Iako je s obzirom na osnovnu kajkavsku akcentuaciju ovaj tip neobičan, on dolazi i u nekim drugim kajkavskim bilogorskim i podravskim graničarskim govorima. Pronađen je u dvanaest lokalnih govora, osim u Reki i u selima: Sedlarica, Ciglena, Veliko Trojstvo, Šandrovec, Gornje Zdelice, Kuštani, Srijem, Povelić, Mali Potočec i Osijek, a vjerojatno dolazi u još kojem. To je i razumljivo za ove govore s obzirom na kontakt s novoštokavskim govorima, jer osim Srba i manji dio Hrvata govori novoštokavski, ijekavski - štokavski i šćakavski.

Razlike su između govora u distribuciji naglasaka, tj. u tome koji naglasak može doći u kojem slogu riječi. U rečkom kajkavskom govoru u načelu nema ograničenja u distribuciji prozodijskih obilježja, odnosno naglasaka - svaki naglasak može stajati na svakom slogu riječi. Prema tome, uzlazni naglasci, i kratki i dugi, mogu stajati i u jedinom i u zadnjem slogu riječi, silazni naglasci mogu stajati u srednjem slogu. Novoštokavska akcentuacija opisana je u osnovi za štokavske govore.

\section{Inventar naglasaka}

\begin{tabular}{|l|c|c|}
\hline & \multicolumn{1}{|c|}{ silazni } & uzlazni \\
\hline kratki & " & \\
\hline dugi & $\frown$ &, \\
\hline
\end{tabular}

Primjeri za naglasak s minimalnim akcenatskim parovima:

sëla 'sjela' - sèla $\mathrm{G}$ jd. - sêla $\mathrm{N}$ mn. od sèlo

zdën 'hladan' - zdèn 2. jd. imp. 'uzdahni'

kûma $\mathrm{G}$ jd. od kûm - kúma $\mathrm{N}$ jd. 'kuma'; pêta broj-péta $\mathrm{N}$ jd. 'peta'

vôz 'kola' G vöza 'natovarena kola'-vóz || vòz (se) imp. od vòzit || vóst nôs (organ) - nós || nòs imp. od nosit 'nosi'

ròdi 3. jd. od 'roditi' - ródi $\mathrm{D}$ jd. od roda; bòst inf., bòd imp. rôd 'rod' - ròd imp. od ròdit 'rodi'; nòs || nós imp. 'nosi'.

(na)nòs(te) || (na)nós(te), (za)vòz || (za)vóz od (za)vòst $\|$ (za)vóst

donès 'donesi' küp, stär imp., cǜ ; brät $\mathrm{N}$ jd. i inf. 'brati', brât sup. pëkel 'pekao', pèkel 'pakao'; mlâda 'nevjesta' - mláda pridj. podèl 'podijeli', podèlt 'podijeliti'

preslóšt || preslošt inf., preslóž || preslož imp. 'presložiti’ zamàsla, preslàtka, rešèta; staláža,

okrúgel || okrúgo, povléič, (po)vléikla.

Silazni naglasak dolazi i na neprvom slogu, uglavnom u tuđicama, rjeđe u domaćim riječima: obêidovat, rafangêiračّ; veterinâr, živinâr, preskûp; reštänt, zafrkänt.

Neke posebnosti: mèni - mèn || mën; ïmena, kòlena, mësta jd. G - mn. NA kôlena, imèna, mêista - G kôlen, imên, mêist; napùst - napüstil-napùsla, prema namètat - namètal - namètala.

Spektrografska analiza naglasaka (Lončarić $1986^{3}$ ) pokazala je: naglasak dugosilazni ( $($ ) silazan je ili uzlazno-silazan, dugouzlazni (') ima dizanje tona.

\section{b) Glasovi}

Izgovor je glasova uglavnom kao u susjednim novoštokavskim govorima, odnosno u književnom jeziku. Kod samoglasnika je jedan izuzetak: na mjestu staroga dugoga jata i poluglasa (koji su izjednačeni) gdje je u novoštokavaca skup ije, u petočlanom vokalizmu, ili dvoglas ie, kao šesti vokal, u kajkavskom rečkom govoru tu je dvoglas ẹi. Sustav je: $i-e i-e-a-o-u$, npr. dijéte || diéte - dêite, sijêno || siêno - sệino, bijêl || biêl - bệil; stêiikla $\mathrm{N} \mathrm{mn}$. 'stakla' - stèkla G jd. 'stakla', prema je ili e u kratkom slogu: djèteta, bjelina - dèteta, belìna; stèza, pèkel 'pakao'. Na mjestu dvoglasa ei u dugom slogu, u kratkom slogu dolazi također poseban samoglasnik, koji je ili kratki dvoglas ili zatvoreno $e$ (što je novije nego razlika dijéte - djèteta), npr. sệikel - pòsẹikel || pòsẹkel, vlẹikel-nàvlẹikel || nàvlẹkel; prệik-pöprẹik || pöprẹk, dệila-nèdẹila || nè-dẹla.

Rađena je u Institutu za fonetiku Filozofskoga fakulteta u Zagrebu te u Kölnu - Institut für Phonetik der Universität. 
Rečeno je da su se stari hrvatski i slavenski samoglasnici jat (ě) i poluglas (a) izjednačili, kao u većini kajkavštine; primjera za jat dosta je naprijed, a za poluglas uz stệikla $\mathrm{N}$ mn. 'stakla' - stèkla G jd. 'stakla', stèza 'staza', još nekoliko primjera: pës, péso - pệisji 'pas - pasji', tẹ́inek, tẹ́inka 'tanak, tanka'; posebno u sufiksima $-e c,-e k$, -el u pridjevu radnom i u tvorbi imenica, naročito umanjenica, i pridjeva te drugim sufiksima, npr. bètvo - bệitva, stéblo, mègla, bèzga 'bazga'; kòsec, stòlec, stòlčec || stòlček, pèsek 'psić', kràtek || krátek; vüzel 'uzao', pòsel, pèkel 'pakao', pëkel 'pekao'.

Kod poluglasa ima izuzetaka, iz sociolingvističkih razloga, npr. redovno je dân, ne dệin, ali u uzrečici je dên dènes 'dan danas'; redovno je pân 'panj', a pëń je 'pločica u igri guranja po tlu'. Pravilno je máček, júnec, ždrẹibec, ali je järac 'ovan' (uz prijenos značenja, ne znači 'kozel').

Kod izjednačenih starih glasova, stražnjega nosnog samoglasnika (o) i slogovnoga $l(l)$ redovno je $u$ : $q$ - rúka || rùka, zûbi, súdec, glâvu, bèru; l - sûza, vûk, žût, sûnce. Iznimke su rijetke, npr. sòbota (uz sùbota), glìbok (i s drugim promjenama).

Kao i u štokavskim govorima došlo je do otpadanja nenaglašenog zanaglasnoga $i$ u više kategorija, tako u pojedinim riječima - gòrce (< gorice)'vinograd', küna (< kuhińa), lisca 'lisica', mòtka 'motika'; DL ličnih zamjenica - mèn \| mën, tèb || tëb, sèb || sëb; infinitiv - brät, pòbrat, spät, zàspat, dìgnit, kòpat, jëst, pöjest, nòst || nóst, nanòst, nájt; - imperativ - bèr, pobèr, nòs || nós, nanòs || nanós, nájd, jëž̆, pöjež '(po)jedi', ali zàspi, spî; dìgni.

Staro početno $u$, zatim ono od $q$, te staro $o$ dobili su protetsko $v$, odnosno $j$, npr. u- - vüčil, vûvo, vûstje, Vùzem 'Uskrs', vuzménka 'uskršnji krijes'; vúzek, vùgel; o- -jöči, jöko, jògeń, jòtec, ali òbluk 'prozor', òrẹij 'orah', òtava, öglavnik, ötprl. Stariji su likovi s protetskim $j \operatorname{kod} a, e$, obično u imenima, npr. Jána, Jándro; Jẹiva (i Eva).

Stari prijedlog i prefiks $v(\partial)(-)$ dali su: $v(-)$ (i dalje $f(-)) \| v u$ - $\| Q$ (ništa): $v=$ v (ï̌u || läče || òbluk || Bärcu || gànek), f (kòtec || štälu || tórbu); Q - (váraš || vr̂̌čak); vdòvec, fpïknil, ftèknil; vu - vù (tom || dvor); vüšel, vùtkala.

Stariji prijedlozi i prefiksi $s(\partial)(-)$ te $i z(\partial)(-)$ slili su se u jedan: $z(-)$ (i dalje $s(-), \check{s}(-), z e(-)$ te $Q . S($ (a) (-) = z (brätom $\|$ mämom $\|$ mënom) - zbúnil, zmàntal, s (tëbom || kölima || pílom || tàvana) - slêikel, stïsnil; š (čèlom || čövekom), ž (ńôm |ńîm) uz š (ńom |ńîm) - ščèknil, ščipal; zèstal, zèsim 'sasvim'; rijetko: zò (tim), uz $s$ (tîm). Iz(o)(-): z - (zï̌̌el je) z (bükve \| grâda \| mëlina || iže) zvlệikel; $s$ - (zï̌sel je) s (komóre \| púta || kòca), š (čăše || čöveka), Q-(döšel je) Q (svätov || škôle || šüme || Zükve || žèpa).
Za suglasnički sustav važno je da postoji samo jedan par mekih afrikata, slivnika, kao u većini kajkavskoga narječja: prema $\check{c}-\dot{c}$ stoji srednje $\breve{c}$ (staro $t^{\prime}<t j$ izjednačilo se sa $\check{c}$ ), a prema $\dot{\zeta}(\check{d}<* d j)$ te $\check{\zeta}(d \check{z})$ srednje $\breve{\zeta}(d \check{c})$, npr. $\check{c}$ - čèlo, čeréivo, čövek, čuvat, cüuden, jëčte (< jeđte), máček, povléič; *tj - òuu

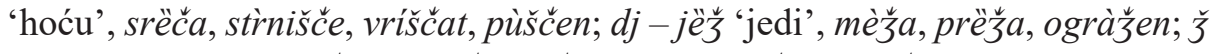

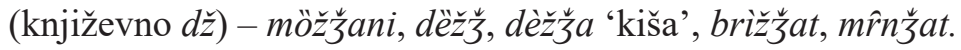

Kao u nekim drugim kajkavskim govorima i dijalektima razvio se zvučni parnjak bezvučnoga $c-3(d z)$, i to od $z$ u skupu zg, npr. bèzga (< bezga) 'bazga', mözga $(<$ mozga) - mözek, brïzgat (< brizgat), drúzgat (< druzgat). Navedeno je da su ga negdje preuzeli i štokavci u kontaktu, tako u Reki.

Spirant $x$ nestao je iz sustava, a negdje je, da se izbjegne zijev, zamijenjen $\mathrm{s}$ $v$ (uz stražnje samoglasnike) ili $j$ (uz prednje samoglasnike): a) $Q$ - grä 'grah', "ža a, smệi 'smijeh', rëko 'rekoh', (jâ) bi (< bih); b) v-dùvan, krüva, küvat, müva, mârva; $j$ - smẹija 'smijeha', snëja 'snaha', grijòta 'grehota', brèjat (< njem. brechen) 'kašljati', dijat 'dihati'. Rijetke su druge zamjene, npr. $\check{s}-$ štëla 'htjela', Štèfek; $k$-dàktat 'dahtati'. Pojavljuje se u govoru pod utjecajem kajkavskih govora koji ga imaju te književnoga jezika, npr. (x)àmbar, (x)âm, (h)üta.

Sekundarni skupovi s $j$. Sačuvali su se skupovi sa $t, d$ : $t j-$ smètje, lîstje, vûstje 'ušće, otvor ložišta na peći', màstjom; dj-pòsudje, grôzdje. U nekih riječi postoje dublete s jotiranjem, npr. cvệitje || cvệiče; rö̧̌̋k je prema starijem röžen. Skupovi s usnenicima nisu dobili $l$, no javile su se dublete prema starijim skupovima $b l$, pl: grôbje, snôpje, gr̂mje, divji, brvjom, prema starijem zöbl̦em,'zobljem', käpḷem, glüpḷi. Skupovi sa $l, n$ jotirani su: $l j>l, n j>\dot{n}$, npr. veséle, zêle; grâne, kòpańe. Od mekanoga staroga vibranta $\left(r^{\prime} \| r j\right)$ između samoglasnika dobiven je skup rj, npr. môrje, škârje, zòrja; pregovárjat, zàmarjam.

U osnovi na kraju riječi dolaze i zvučni šumnici, a ne samo bezvučni kao u većini kajkavštine (kao i u slovenskom i drugim slavenskim jezicima), npr. pórub, mlâd, mräz, râž, br̂̀v (a ne porup, mlat - mladi, mras, raš - raži, brfbrvi). Nakon većih doseljavanja kajkavaca iz drugih područja, posebno nakon II. svjetskoga rata, dolazi do raspodjele da na kraju stoje samo bezvučni šumni suglasnici, tako da se čuje danas molitva sa izgovorom i plôd ûtrobe tvòje te također i plôt ûtrobe tvòje.

Kao i kod novoštokavaca razvili su se dugi suglasnici, nakon otpadanja zanaglasnoga $i$, tako dugo $l, n, t$ (što ovdje pišem dvostrukim slovom - $l l, n n, t t$ ), npr. mòlla $(<$ molila), sòlla $(<$ solila $)$, slànna $(<$ slanina $)$, (môram) plàtt 'platiti' || mlátt 'mlatiti' inf. (prema daj / plàt || mlát imp.). 


\section{Morfologija}

U morfologiji nema dvojine, no sačuvali su se oblici za nekoliko riječi, odnosno sveza i fraza u konstrukciji s brojevima 2, 3, 4 (dvệi || trî || čètri) lete (uz $d v a ̂||$ trî $\|$ čètri leta). U promjeni izostaju rezultati sibilarizacije, zamjene $k, g$, $h$ sa $c, z, s$, npr. mn. imenica o-osnova vûki(ma), glògi(ma), pûvi(ma) (ne pusi < puhi) 'puhovi'; jd. DL imenica a-osnova, npr. müki, kvr̆gi, müvi (ne musi < muha); u pèč (te) generalizacija je osnove iz prezenta pècem ... (ne pec/te/, prema pekel.

U glagola sačuvan je supin. Većinom je došlo do izjednačenja infinitiva i supina nakon otpadanja -i u infinitivu, npr. (idem, kao i kod moram) kòpat $\|$ rëzat Il popéivat (infinitiv je bio kopati, rezati, popẹivati). Razlika se vidi kod glagola koji imaju različit naglasak u inf. i sup., npr. (idem) brât $\|$ spât $\|$ jêist; (idem) vlêič || örat || kösit || pöstit, ali (moram) brät || spät || jëst; (moram) vlẹič || òrat || kòst || pòst. Posebnost: sup. (idem) glêt - inf. (moram) glédet.

Kod glagola karakteristično je također da nema proširenja osnove u 3. mn. prezenta, čuvaju se stariji nastavci: bèrem - bèru, vîčem - vîču, vîdim - vîde, nösim - nöse, kupòvat - kupújem - kupúju, köpam - köpaju; u glagola sa zamjenom $k \| \check{c}$ (pekel-pečem) generalizirana je osnova sa $c \check{u}$ 3. mn. prezenta $\mathrm{i}$ imperativu, npr. pèčem, sẹič́em - pècu, sẹicư - (daj) pèč(te), sẹicü(te). Neke posebnosti: višs(te), glè(te); sëst si-sëdni si.

Imenice. Nema vokativa, odnosno sinkretizam je, isti je oblik za nominativ, npr. brät || sèstra, kàkov || kàkva si ti brät || sèstra. Prežitak je Böže, İsuse uz Bôg, İsus (Böže || Bôg môj). Muški rod, o-osnove: u imenice koje znače neživo A bez prijedloga jednak je G, npr. (vidim) stòla, štáglja, púta kao bräta, kòna, ali (dët) na pôd $\|$ stöl, (idem) $f \|$ pred štágelj, (idem) na pût. U I jd. nastavci su -om || -em, npr. brätom, gräbom, sînom, vùglom - kònem, kostáńem, (j)òcem, stòlcem. U mn. nema proširenja sa ov $\|$ ev, a u G nastavak je -ov \|| -ev, npr. stòli, vòli, mïsi, kräji, púti -stòlov, vòlov, mïšev, kräjev, pútev. a-osnove: u jd. DL imaju nastavak -i, npr. báki, iži, stèzi, 'stazi', brïgi; u I nastavak je -om, kao u o-osnova, npr. bákom, ižom, stèzom, brïgom; isti nastavak dobile su imenice i-osnova, umjesto $-u$, na $j$, pa je nastavak sada -jom, npr. màstjom, br̀vjom, mlädostjom. G mn. ima većinom nastavak $-\alpha$, nulti nastavak (tj. nema nastavka), kao i imenice s. r., a čest je također nastavak -i. Negdje su dublete, npr. ž. r. krâv, nôg, žên; jágod, mègli, s dubletama stèzi \|stêz, dèski || dệisek, glâv || glávi, gûsek || güski, jábuk || jäpki; s. r. leit 'ljeta', mệist 'mjesta', sêl; pôl 'polja', şrç, striniščc.
U mn. došlo je do sinkretizma DLI, ti padeži imaju jednak nastavak: a-osnove imaju nastavak -am, a ostale sklonidbe -ima, npr. ǐžam, livadam, sùsedam (od sùseda), žènam - starèšnam, slúgam, sùsedima (od sused); brvima, màstima, rädostima - kônima, kostáńima, lóncima || lòncima; lëtima, mëstima, pölima, šrcima, str̀niščima. Ima u LI okamina starijega stanja, s dubletama: (na \|z) kôli || kôlima, sêli || sêlima, kôni || kônima || kònima, vôli || vôlima || vòlima, vrâti $\|$ vrâtima \| vràtima. Prežitak je lik za L jd. (po) sêli, uz sêlu te (pri) vràgi.

Pridjevska sklonidba ima o\|le nastavke, npr. dòbrog(a), dòbrom(e); ònog(a), ònom(e) - vrúčeg(a), vrúčem; mläjšeg(a), mläjšem; mòjeg(a) \| môg(a), mòjem || môm. Komparativ ima sufikse -eš-, -ij-, npr. nòveši || nòviji, bogàteši || bogàtiji, sigùrneši || sigùrniji. Negdje je stariji ili posebni lik, npr. glìpši || glibeši, lëpši, jäkši || jäči, vǐši || višeši ci mläjši, släjši (uz slàtkeši ).

Značajno je za lične zamjenice: GA mène, tèbe - I mènom, tèbom. Neke posebnosti u brojeva: dvàjst (20), trìst (30).

\section{Leksik}

U rječničkom blagu ima uz općehrvatski i općekajkavski fond malo posebnosti, ne navodim primjere zbog prostora. Od tuđica najviše je germanizama, malo je hungarizama, a ima i turcizama. Primjeri: germanizmi - brèjat 'kašljati', pâjtlat 'mijenjati žito za brašno', šàmerlin 'vrsta stolčića', vürmokar 'urar', vàktarna 'željeznička čuvarnica'; hungarizmi - aldòmaš 'likov', bäca 'braco, striko', čěča 'teta, za stariju ženu', čóka 'teta, za stariju ženu', ègede 'violina'; turcizmi - divánt se 'razgovarati', drüm 'cesta'.

Navodim samo dva semantička polja: i) jedno se odnosi na osnovno značenje 'repa', vidi se tvorba i razlikovanje značenja: a) rëpa 'repa, bijela okrugla'; b) rëpce 'krumpir', c) cükorca 'duguljasta repa, obično crvenkasta, nije šećerna repa'; c) cükorepa 'šećerna repa'; e) róna 'cikla' (dijalektno njemački 'cikla'); f) rëp(i)ca || repica 'biljka za ulje'; ii) drugo se odnosi na crijevo, trbuh: dróbo, créivo znače 'crijevo', čeréivo je 'trbuh'.

\section{Imena}

Kako su imena, i osobna i zemljišnih objekata, značajan dio identiteta nekoga govora, mjesta, kraja, osvrćem se i na četiri imenske kategorije u rečkom govoru: a) neslužbenu imensku formulu, tj. kojim se imenom od jedne riječi ili svezom više riječi identificira neki čovjek; b) tvorbu živih imena, tj. oblikom 
imena kojima se obično obraćamo nekom čovjeku; c) mikrotoponimiju, imena rudina - polja, zemljišta i zemljišnih objekata (donose se primjeri i za štokavske govore, pa se upotreblavaju i glasovi $c ́, \breve{c}$, uz kajkavsko $\breve{c}$ ); d) ekonimi, etnici i ktetici iz rečkoga okružja.

\section{Imenska formula}

Neslužbena imenska formula, kako se naziva, identificira pojedinac, može biti jednočlana i višečlana, a najčešce je dvočlana.

Kada je samo jedan član, to može biti:

\begin{tabular}{|c|c|}
\hline $\begin{array}{l}\text { - rijetko osnovno ime } \\
\text { - rijetko ime u osnovnoj varijanti } \\
\text { - rijetko prezime u obliku: - za m. r. } \\
\text { - za ž. r. } \\
\text { - nadimak koji karakterizira }\end{array}$ & $\begin{array}{l}\text { Ivok, Tominec, Zêfa }(<\text { Elizabeta) } \\
\text { Blâž, Jäkup, Fánca, Mìjek - Mijèka, Mìok- } \\
\text { Mijòka } \\
\text { Mräz, Mlàdić, Tàšnerer } \\
\text { Mrazòfka, Fèletarka } \\
\text { Bâs (povratnik iz SAD tako se nazivao - } \\
\text { eng. ... boss) }\end{array}$ \\
\hline $\begin{array}{l}\text { - uzrečice osoba } \\
\text { - nadimak porodice } \\
\text { nadimak po porijeklu } \\
\text { zanimanju } \\
\text { rodbinstvu }\end{array}$ & $\begin{array}{l}\text { Bögadâl, Lẹiipa Mòja } \\
\text { Jǒškič, Mìlofći \| Mìlofči, Périćka } \\
\text { Vrbovčan, Jagñedovčánka } \\
\text { Bäčvar, Kòvač, Šikutor, Zòonar } \\
\text { Strîc, Séka, čóka. }\end{array}$ \\
\hline
\end{tabular}

U dvočlanoj odnosno višečlanoj formuli redovno je prvi član ime (rodno, krsno), odnosno ona riječ koja služi kao ime, npr. Séka, Tétec. Ime dolazi u varijanti koja se veže za jednu osobu, tj. za jednu osobu veže se jedna varijanta osnovnoga imena, invarijantno za drugu osobu druga inačica. Događa se da se jedna varijanta veže za više osoba, a neka samo za jednu osobu. Primjeri varijanti dvaju imena Ívan - Ívo, Ïvica, İvek, Ívec, İvok, Ivina, Ívić \|I Ífć; Katarína - Káta, Katèna, Kàtica, Katìca, Kát(i)ć.
Drugi član može biti:

\begin{tabular}{|c|c|}
\hline $\begin{array}{l}\text { - posvojni pridjev prezimena } \\
\text { za ž. r., rjeđe } \\
\text { - prezime, rjeđe (obilježeno: stranac) } \\
\text { - prisvojni pridjev po nadimku porodice } \\
\text { za ž. r } \\
\text { - posvojni pridjev očeva imena ili nadimka } \\
\text { - posvojni pridjev majčina imena ili nadimka } \\
\text { - pridjev muževa imena ili nadimka } \\
\text { - član koji karakterizira } \\
\text { - nadimak po porijeklu } \\
\text { - član koji lokalizira } \\
\text {. }\end{array}$ & $\begin{array}{l}\text { Jüšćev \| Jüšćeva, Treščěčev \| -čeva, } \\
\text { Jüšićka, Kölarićka } \\
\text { Fûtač, Siròvec } \\
\text { Jöškičev, Tómčev, Mìlofćev } \\
\text { Périćka, Tómićka, Jäićka } \\
\text { Jožinov, Jöžekova, Tomínčev } \\
\text { a Söfin, Zëfin, Júlkin } \\
\text { Mijèkova, Mijoókova, Ivókova, Milofćeva } \\
\text { Kïsela, Dèbeli, Šäntavi, Lúda } \\
\text { Prekogórec, Prekógorka, Mážrka } \\
\text { Z vùgla, Od pòtoka \| Mej́e (književno } \\
\text { Međee), Z Domája. }\end{array}$ \\
\hline
\end{tabular}

U tročlanim formulama uz one oznake koje dolaze u dvočlanima javlja se također genitiv imena:

\begin{tabular}{|ll|}
\hline - očeva & Milǒsa Mìlofčevog $\|$ Milovčevog, Mijèka Jüšćevog || Jüščevog \\
- muževa & Jöžeka Lònčarćevog, Stéve Jägotćevog \\
- majčina & Släve Zëfine, Sâfke Döbrnćeve. \\
\hline
\end{tabular}

\section{Tvorba ekspresivnih imena}

Dominantne glavne varijante ekspresivnih imena tvore se ovim modelima:

a) sufiksima za muške i ženske osobe:

\begin{tabular}{|c|c|}
\hline $1-e k$ & İvek-İveka \|Ivèka, Bàrek-Bàreka \| Barèka \\
\hline $2-i c ́$ & Jǒškič, İvić $\|$ İf́ć, Bärič $\|$ Bärč \\
\hline $3-e c$ & Ívec-Ífca, Bárec-Bárca \\
\hline $4-i c a$ & Ïvica, Bárica $\|$ Barìca, Kàtica $\|$ Katìca \\
\hline 5 -ina za $\mathrm{m}$. & Ivina, Štefina \\
\hline 6 -ena za ž. & Barèna, Marèna, Katèna \\
\hline 7 -ok za m. & İvok-Ivóka. \\
\hline
\end{tabular}

b) kraćenjem osnovnoga samoglasnika:

Ïva, Stëva; Bära, Mära - prema Ívo, Stévo; Bára, Mára. 


\section{Mikrotoponimi}

Mikrotoponimiju je opisala Anđela Frančić u radu Rečka mikrotoponimija. Vidi se različito pisanje istih glasova jer postoje obično i štokavske i kajkavske varijante istih imena, $\mathrm{s}$ jedne strane, a donose se i varijante iz Katastra kako su tamo zapisane. Autorica donosi načine tvorbe mikrotoponima u rečkom kajkavskom i štokavskim govorima. Donosim nekoliko dopuna.

\section{Mikrotoponimi nastali onimizacijom}

Parlok (: mađ. parlag 'parlog, neugarena njiva'). Parlog je od slavenskoga prelog.

\section{Izvedeni mikrotoponimi}

Sufiksima mjesnoga značenja: -(ov)ec: Bukovec; -(in)ec: Čmelinec (: čmela 'pčela'); -jak: Zečjak; -ek: Polaček; -ik: Jalšik (: jalša 'joha'), Višnjik; -(ov)(i) ca: Mesarca, Rastovica (: (h)rast), Sjenica.

Sufiksalne izvedenice tvorene od imena, i to: od antroponima sufiksima -ica, -ina, -uša; tako nastalim mikrotoponimima kazuje se vlasnost, posvojnost osobe čiji je antroponim u osnovi mikrotoponima nad imenovanim mikroobjektom, iako u mikrotoponimijskoj postavi izostaje posvojni sufiks: Blašca, Bogdanca, Jandrašica, Štimčina, -uša (Čubakuša nadimak < čubak 'čovjek u koga su velike usne'); Jankuša, Karačuše (nadimak < karač ‘čovjek koji se kara').

\section{Dvorječni mikrotoponimi}

Prijedlog + imenica u nominativu - Za ograda, Za straža. Ovdje bi bila točnija interpretacija da se radi o jednorječnom nazivu, tj. imena glase: Podgnojnice Zaograda, Zastraža - prijedlog i imenica dali su novu riječ, kao u Nadograda, Podograda.

\section{Aloglotski elementi u rečkoj mikrotoponimiji}

Uz idioglotske (hrvatske, slavenske) lekseme u rečkoj mikrotoponimiji prepoznajemo i takve koji imaju ishodište u aloglotskim (drugojezičnim, neslavenskim) jezičnim sustavima: - mađarskom: pandur 'stražar; policajac' (Frančić 2003).
Riječ je slavenskoga porijekla, isti je korijen kao u pudar.

Parlog. mađ. parlag 'parlog, neugarena njiva'

Naveo sam da je to od slavenskoga prelog.

$\mathrm{U}$ Abecednom popisu rečkih toponima te u bilješci 25. autorica navodi da za narodna imena Átove, Pòdove u Katastru stoje likovi Atovi, Podovi. Sigurno ih je napravio službenik po pučkoj etimologiji, da bi dobio prepoznatjive i ,pravilne" likove. Likovi Átove, Pòdove gramatički su pluralia tantum, ženskoga roda, kao Dòlne, Küćne, samo što su neovjereni s obzirom na gramatički i semantički odnos.

Autorica (Frančić 2003: 385) na kraju u Zaključku veli:

„Usporedbom Popisa katastarskih čestica i stvarnoga stanja na terenu uočili smo da podosta imena iz Popisa ne živi u narodu i Rečani ih uglavnom ne prepoznaju kao imena svojih njiva, livada, šuma. Detaljnije bavljenje rečkom povijesnom mikrotoponimijom pokazalo bi je li riječ o nekad postojećim, a danas zaboravljenim imenima zemljišnih čestica ili o tzv. administrativnim imenima koja nikad nisu živjela u narodu."

\section{Ekonimi, etnici, ktetici}

Donose se: a) ekonimi - imena naselja, naseljenih mjesta, iz okružja sela Reka; b) njihovi etnici - imena stanovnika; c) ktetici - njihovi pridjevi. Navode se standardni, književni likovi imena i pridjeva te rečke inačice.

Redovno postoje dvije inačice, dva lika imena i pridjeva rečka: (novo)štokavski i kajkavski, što se posebno ne naznačuje. Kajkavske inačice na mjestu standardnih i štokavskih parova afrikata $\breve{c}-\boldsymbol{c}$ imaju po jednu, srednju afrika-

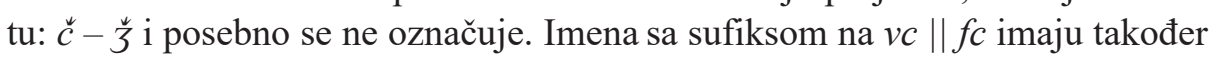
dva lika: štokavski s nepostojanim $a-$-ovac/-ofca i kajkavski s nepostojanim $e-$-ovecl-ofca. 


\section{$\underline{\text { Reka }}$}

Réčan, Reičan, R(ij)éčanac, Reíčanec; Staro- \| Novo- réčan \| reíčanec...

R(ij)éčanka, Reíčanka

rečki, riječki, rệički; réčanski, rijéčanski, rệičanski; staro- || novo- rečki || rệički...

Za ime općine Mučna-Reka treba reći da se pisalo i Mučna Reka, kao što se pisalo i za željezničku postaju: stanica Mučna Reka i (danas) Mučna-Reka. Ime se odnosi na dva sela: Reka i Velika Mučna. Postaja je između njih.

Koprivnica Kòprivnica (većina kajkavskih sela u okružju ima Koprîvnica, kao i većina grada)

Koprivničánac/-nca || Koprivničánec/-nca, Kòprivničan; Koprivničánka

kòprivnički, koprivničânski (Kajkavci su obično govorili váraš / Váraš, G váraša /

Váraša; váraški; otuda i Váraške gòrce za Vinicu.)

Vinica Váraške gòrce

Nisu bili obični etnici i ktetici, identificirali su se opisno, npr. (i)z Várški gôric.

Paunovac Pànovljani, Päunovac

Panovlánčan || Panovlánčan \|; Panovlánčanka || Panovlánčanka;

pànovlanski, panovlánčanski $\|$ panovlánčăanski

Paunovčánac/-nca || Paunovč́nec, Paunóvčan; Paunovčánka; päunovčanski

Velika Mučna, Mala Mučna

Za oba sela upotrebljavali su se obično isti oblici, a većinom su se odnosili na susjedno mjesto Velika Mučna: Múčanac/-nca || Múčanec/-nca; Múčanka || Múčanka;

múčanski \| múčanski. Kad se radilo o selu Mala Mučna (šaljivo: Mala Moskva),

obično se dodao prefiskoid malo- malomúčanski, ili opisno (i)z Mâle Mûčne.

Domaji (Općina Sokolovac, sada), Domaje (Mučansko) (Općina Mučna-Reka)

(Múčansko || Múcúansko) Domáje

Domájčan || Domájčan; Domájčanka || Domájčanka; domájčanski || domájčanski

opisno: (i)z Múčanskog || Múčanskog Domája

Vrhovac Vrhovac/-ovca, Vrhovec/-ofca Vrhovčan || Vrhofčan; Vrhovčánka ||

Vr̉hofč́ánka; vìhovački || vìhovečki, vrhovčanski || vìhofčanski

Jankovac Jánkovac/-ovca ||Jânkovec/-ofca

Jánkovčan || Jânkofčan; jánkovački || jânkovečki

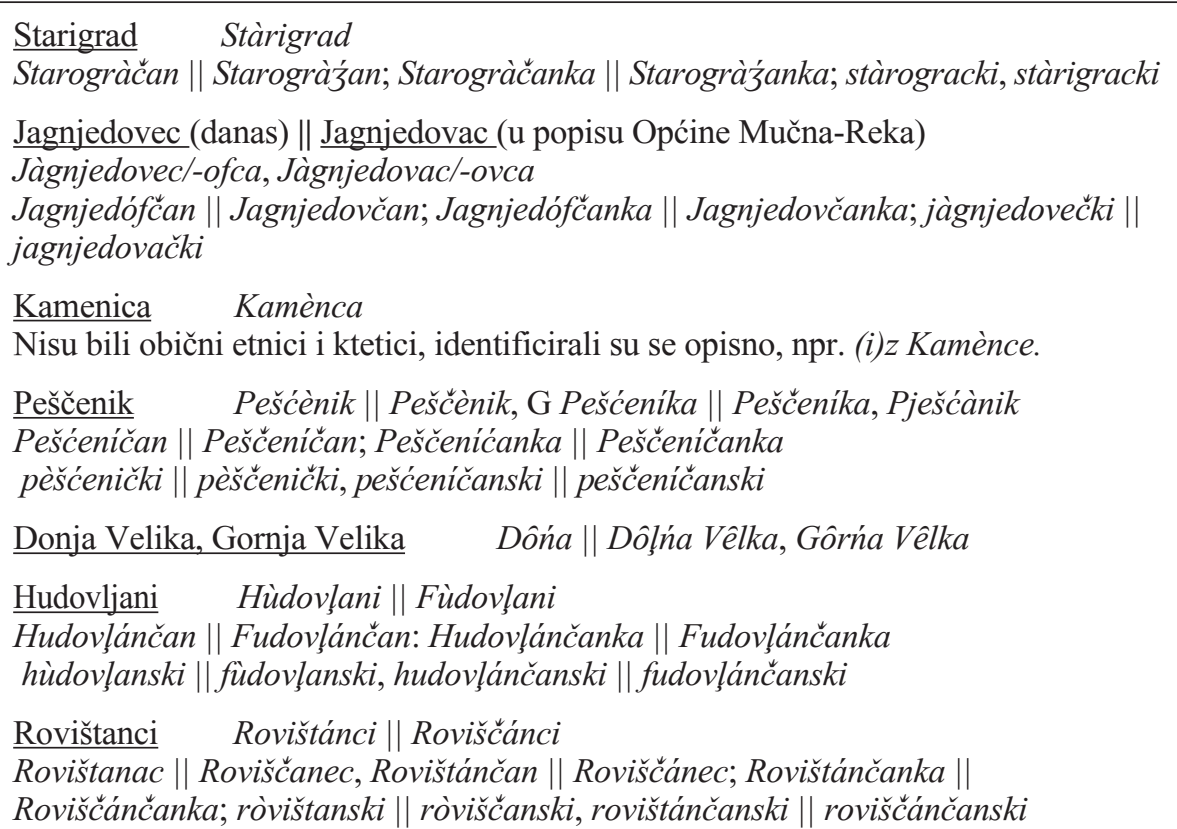

Sokolovac Sokòlovac/-ovca || Sokòlovec/-ofca

Sokòlovčan || Sokòlofčan, Sokolovčánac || Sokolofč́ánec; Sokolovčánka; sokòlovečki, sokòlovčanski

$$
\text { Mjesto se ranije zvalo Kukavica. }
$$

Lepavina Lëpavina

Lepavinčan || Lepavínčan; Lepavinčanka || Lepavinčanka; lëpavinski, lepavinčanski

Miličani Mìličani $\|$ Mìličani

Miličánac || Miličánec; Miličánčanka; mïličanski || milličanski, miličánčanski

Brđani Sokolovački Br̀z̧ani || Br̀̆̌̌ani

Donjara Dònara

Donjárčan || Donjárčan; Donjárčanka; dònjarski, donjárčanski

Donji Maslarac, Gornji Maslarac Dộńi || Dôńi Maslárac || Dôlńi Maslári; Gôrńi Maslárac \| Gôrńi Maslári

Maslárčan || Maslárčan; Maslárčanka; màslarski, maslárčanski

Srijem $\quad$ Srijêm $\|$ Srêim || Srêm, G Srijéma \| Sreíma \| Sréma

Srijémčan || Sreímčan || Srémčan; Srijémčanka || Sreímčanka || Srémčanka

srệimski || srêmski, srijémčanski || srẹimčanski || srémčanski 


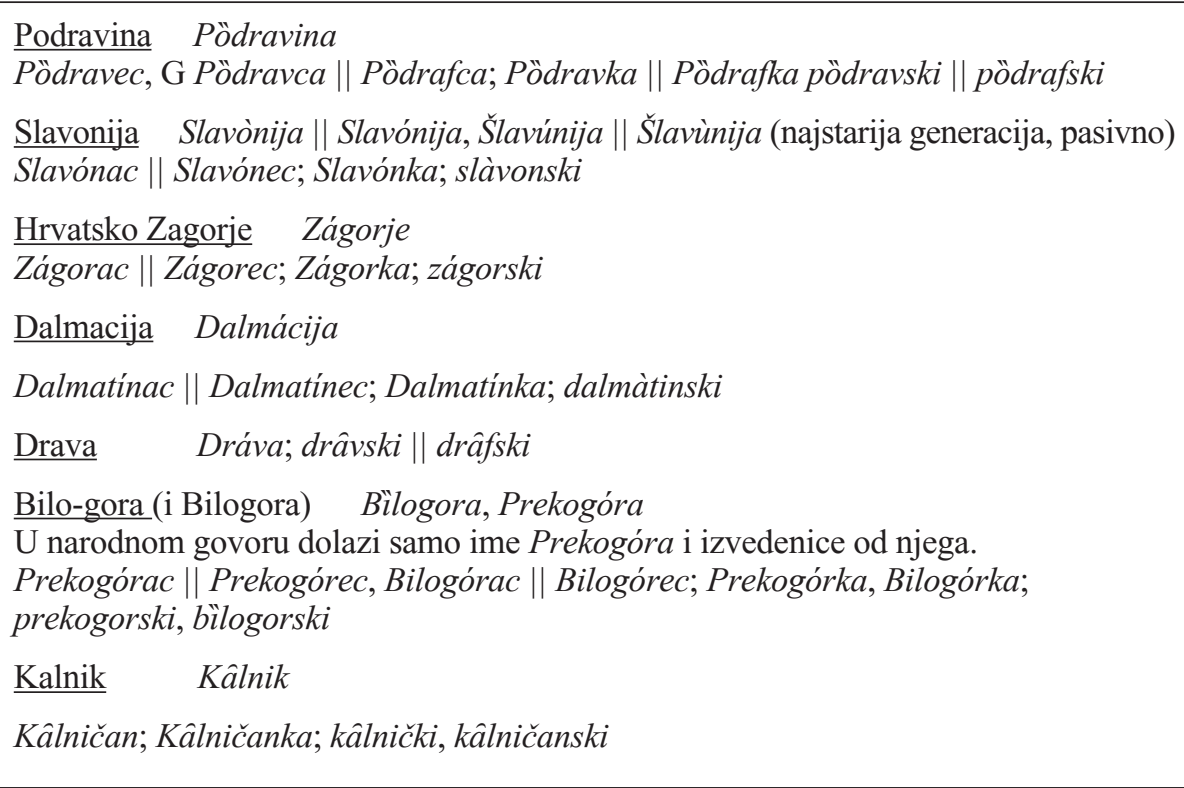

\section{Međimurje Mež̉imorje, Meśìmurje}

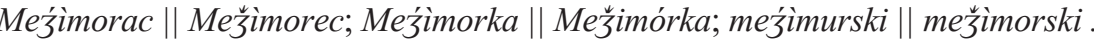

$\mathrm{U}$ narodnom govoru dolazio je samo lik Me ̌̌imorje i izvedenice od njega. U

književnom kajkavskom jeziku postojala je riječ, apelativ mešimorje, što znači

„otok“; latinski se Međimurje zvalo Insula 'otok'. Pučkom etimologijom, krivo, kad

je nestala riječ, apelativ mešimorje, povezalo se ime pokrajine s imenom rijeke Mura,

pa se umjesto pravilnoga Međimorje napravilo novo, krivo ime Međimurje (Lončarić 1995).

Zagreb Zâgreb \| Zágreb

Zägrepčan || Zâgrepčan || Zágrepčan, Zägrepčan || Zâgrepčan || Zágrepčan

Zägrepčanka || Zâgrepčanka || Zágrepčanka; zägrebački || zâgrebački || zágrebački

Bêč $\|$ Bêč

Béčan || Béčan; Béčanka \| Béčanka; bêčki || bêckki, béčanski \| béčanski

Srbija Srbija

Srbijánac || Srbijánec; Srbijánka; srbijanski

Bosna

Bösna

Bosánac || Bosánec; Bosánka; bòsanski

Hercegovina Hèrcegovna $\|$ Ėrcegovna

Ėrcegovac || Hèrcegovac /-ovca, Ėrcegovac || Hèrcegovec /-ofca; Èrcegovka |

Ercegofka, Hèrcegovka || Hèrcegofka;

hèrcegovski || èrcegofski, hèrcegovački || èrcegovački

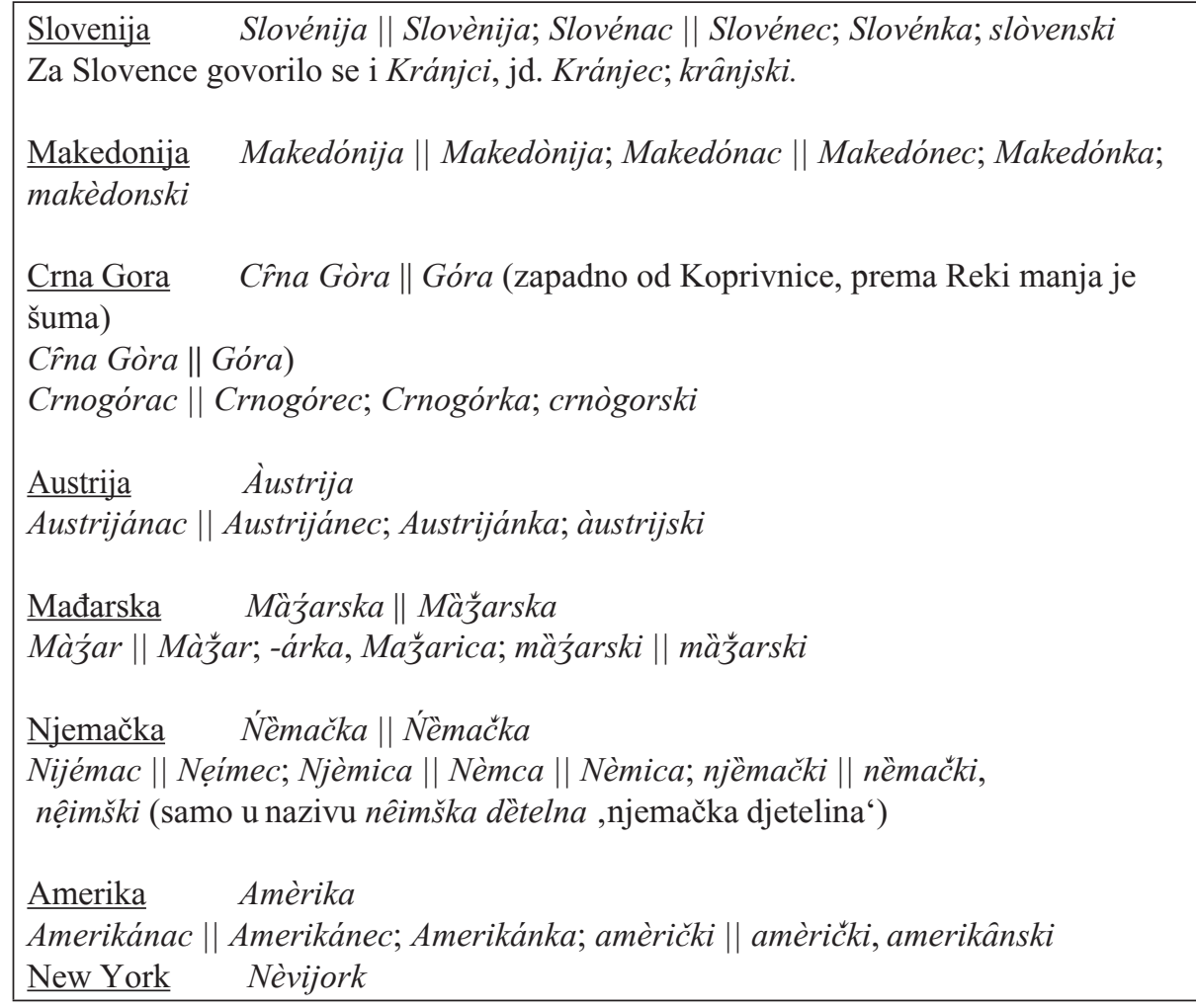


Literatura:

API (i IPA) - Alphabet Phonetique International. 2015. The Principles of the International Phonetic Association. International Phonetic Association.

Brozović, DALIBOR. 1963. O rekonstrukciji predmigracionog mozaika hrvatskosrpskih dijalekata. Filologija 4. 45-55.

Budak, Neven. 1994. Prva stoljeća Hrvatske. Hrvatska sveučilišna naklada. Zagreb.

FAnCEV, Franjo. 1907. Beiträge zur serbokroatischen Dialektologie: der kajDialekt von Virje, mit Berücksichtigung der Dialekte Podravina's. Archiv für slavische Philologie 29. 305-389.

FranČÍ́, ANĐELA. 2003. Rečka mikrotoponimija. Rasprave IHJJ 1/29. 373389.

GoldsteIn, Ivo. 1995. Hrvatski rani srednji vijek. Novi Liber - Zavod za hrvatsku povijest Filozofskog fakulteta. Zagreb.

Ivić, AleKsa. 1926. MigracijeSrba u Slavoniju tokom 16.,17. i 18. stoljeća. Srpska kraljevska akademija. Subotica.

Ivić, PAVLE. 1958. Die serbokroatischen Dialekte: Ihre Struktur und Entwicklung. Erster Band, Allgemeines und die štokavische Dialektgruppe. Mouton \& co. 'sGravenhage.

IvŠić, StJEPAN. 1936. Jezik Hrvata kajkavaca (s kartom). Ljetopis JAZU 48. 47-88.

Kapović, Mate. 2015. Povijest hrvatske akcentuacije. Fonetika. Matica hrvatska. Zagreb.

KAŠIĆ, DušAn. 1967. Srbi i pravoslavlje u Slavoniji i sjevernoj Hrvatskoj. Savez udruženja pravoslavnih sveštenika SR Hrvatske. Zagreb.

KaŠIĆ, Jovan. 1963. O jekavskom govoru Velikog Grđevca. ZFL 6. 149-157.

Klaić, Nada. 1971. Povijest Hrvata u ranom srednjem vijeku. Školska knjiga. Zagreb.

KRAJČOvič, Rudolf. 1974. Slovenčina a slovanské jazyky I. SPN. Bratislava.

KRIVOŠIĆ, STJEPAN. 1983. Stanovništvo Podravine 1659.-1859. Podravski zbornik 83. 149-166.

LisAC, Josir. 2003. Hrvatska dijalektogija 1. Hrvatski dijalekti i govori štokavskog narječja i hrvatski govori torlačkog narječja. Golden Marketing - Tehnička knjiga. Zagreb.

LONČARIĆ, MuJo. 1978. Jagnjedovački govor (i karta). HDZ 4. 179-262.

LONČARIĆ, MuJo. 1980./1981. Sjevernomoslavački kajkavski govori. Rasprave Zavoda za jezik IFF 6-7. 55-120.
LONČARIĆ, MiJo. 1982. Prilog podjeli kajkavskoga narječja (s kartom narječja). HDZ 6. 237-246.

LONČARIĆ, MiJo. 1985. Kalničko-bilogorska štokavština. HDZ 7/1. 133-150. LONČARIĆ, MiJo. 1986. Bilogorski kajkavski govori Rasprave Instituta za hrvatski jezik 12.

LonČARIĆ, MiJo. 1990. Jezični odnosi u Podravini. Arheološka istraživanja u Podravini i kalničko-bilogorskoj regiji. Ur. Majnarić-Pandžić, Nives. Hrvatsko arheološko društvo. Zagreb. 181-191.

LonČArić, Mijo. 1995. Toponim Međimorje/Međimurje. Studia Slavica Savariensia $2.15-22$.

LONČARIĆ, Muso. 1996. Kajkavsko narječje. Školska knjiga. Zagreb.

LonČArić, Miso. 1998. Jezični odnosi u donjoj Panoniji. Zbornik Filozofickej fakulty Univerzity Komenského, Philologica XLV. 145-153.

LoNČARIĆ, Miso. 2007. Štokavsko-kajkavski odnos na kalničko-bilogorskom području. Zbornik Matice srpske za filologiju i lingvistiku 50. 459-472.

LonČArić, Miso. 2009. Govor Koprivnice i Podravine nekad i danas. Podravina 15. 139-152.

LoNČARIĆ, Miso. 2013. Reka (kod Koprivnice), obrađeni upitnik kajkavskoga govora za Hrvatski jezični atlas. (rkp., Institut za hrvatski jeziki jezikoslovlje)

Matasović, Ranko. 2008. Poredbeno povijesna gramatika hrvatskoga jezika. Matica hrvatska. Zagreb.

Milivojević, Vladimir. Reka: povijest, priče, ljudi. (monografija, rkp., pripremljeno za tisak)

OKUKA, MıLoš. 2008. Srpski dijalekti. SKD Prosvjeta. Zagreb.

PavičIĆ, StJePAn. 1994. Podrijetlo hrvatskih i srpskih naselja i govora u Slavoniji. Privlačica. Vinkovci. (Pretisak, priredili i prikazali E. Barić, M. Lončarić)

Pavleš, Ranko. 2001. Koprivničko i Đurđevečko vlastelinstvo. vlastita naklada. Koprivnica.

PAVleš, RANKo. 2013. Podravina u srednjem vijeku. Meridijani. Koprivnica.

Petrić, Hrvoje. 2005. Koprivnica u 17. stoljeću: okoliš, demografske, društvene i gospodarske promjene u pograničnom gradu. Meridijani. Samobor.

Petrić, Hrvoje. 2012. Pogranična društva i okoliš. Varaždinski generalat i Križevačka županija u 17. stoljeću. Meridijani. Samobor - Zagreb.

Petrić, Hrvoje; ŠKILJan, FiLIP. 2017. Iz povijesti Srba u Varaždinskoj županiji od prvih doseljavanja do današnjih dana. Grafocentar. Zagreb.

Popović, Ivan. 1960. Geschichte der serbokroatischen Sprache. Harrassowitz. Wiesbaden. 
RAMOVŠ, Fran. 1929. Slovenački jezik. Narodna enciklopedija IV. Zagreb. 129-208.

Rem, Vladimir. 1993. Tko su šokci? Privlačica. Vinkovci.

RešEtar, Milan. 1907. Der štokavische Dialekt. Kaiserliche Akademie der Wissenschaften. Wien.

Strohal, Rudolf. 1920. Dijalekti u današnjoj Bjelovarsko-križevačkoj županiji. Nastavni Vjesnik 28. 412-416.

ŠEKLI, MATEJ. 2013. Zemljepisnojezikoslovna členitev kajkavščine ter slovensko-kajkavska jezikovna meja. Slovenski jezik / Slovene Linguistic Studies 9. 3-53.

Hrvatski mjesni rječnik. 2016. Ur. Bašić-Kosić, Nataša. Leksikografski zavod Miroslav Krleža. Zagreb. (Istražio sam za Rječnik kajkavske i dio štokavskih govora Bilogore, Podravine te još neka manja područja i pojedina kajkavska mjesta.)

Review of Kajkavian and Štokavian idioms of Reka near Koprivnica

\begin{abstract}
People in Reka speak altogether three idioms of Kajkavian and Štokavian: one Kajkavian with three varieties and two Štokavian ones. Most Croats speak, or spoke, Kajkavian, while fewer speak the East-Bosnian Ijekavian-šćakavian dialect. Serbs speak the Neoštokavian Ijekavian („Neoštakavian”, the interrogative pronoun is $\check{s} t a$ ) East-Herzegovinian dialect. I have reviewed the Kajkavian idiom in the monograph Bilogorski kajkavski govori (Kajkavian idioms of Bilogora), and the Štokavian ones in the article Kalničko-bilogorska štokavšti$n a$ (Štokavian idioms of Kalnik and Bilogora). Since the Kajkavian idiom is my native idiom, I undertook a research of it for the Croatian language atlas (point 37a). I make a hypothesis about a language in Podravina before migrations, I speak about how the village emerged and I present the main characteristics of the idioms. I draw parallels with the neighbouring idioms as well.
\end{abstract}

Ključne riječi: kajkavski, štokavski, hrvatska dijalektologija, Podravina, Reka Keywords: Kajkavian, Štokavian, Croatian dialectology, Podravina, Reka 